\title{
Studies on Mutagenic Effectiveness and Efficiency of Gamma Rays, Ethyl Methane Sulphonate, Nitrosoguanidine, Maleic Hydrazide and their Combination in Greengram (Vigna radiata L. Wilczek)
}

\author{
Tapas Ranjan Das ${ }^{1 *}$, Bhabendra Baisakh ${ }^{2}$ and Arjun Mohan Prusti ${ }^{2}$ \\ ${ }^{1}$ ICAR-IARI Regional Station, Pusa, Samastipur, Bihar, India \\ ${ }^{2}$ Department of Plant Breeding and Genetics, OUAT, Bhubaneswar, Odisha, India \\ *Corresponding author
}

\section{A B S T R A C T}

\begin{tabular}{|l|}
\hline Ke y w o r d s \\
Chemical mutagens, \\
Gamma rays, \\
Greengram, \\
Mutagenic \\
effectiveness, \\
Mutagenic \\
efficiency \\
\hline Article Info \\
\hline $\begin{array}{l}\text { Accepted: } \\
\text { 20 December } 2020 \\
\text { Available Online: } \\
\text { 10 January } 2021\end{array}$ \\
\hline
\end{tabular}

\section{Introduction}

Greengram [Vigna radiata (L.) Wilczek] is one of the important food legumes in India. It is a cheap source of dietary protein for the poor, with high levels of folate and iron compared with many other legumes (Keatinge et al., 2011). Due to the lack of sufficient natural variability, conventional methods of plant breeding had limited scope for the improvement of this crop. Mutation breeding using individual and combined
Mutagenic effectiveness and efficiency of gamma rays, Ethyl methane sulfonate (EMS), Nitrosoguanidine (NG), Maleic hydrazide (MH) and their combined treatments were studied in greengram. The percentage of lethality, pollen sterility, frequency of chlorophyll mutations, mutagenic effectiveness, mutagenic efficiency and mutation rate of each mutagen and their combination treatments were estimated to determine the mutagenic effect of these mutagens and their combinations. The result indicated that the values of mutagenic effectiveness gradually decreased with increases in dose/concentration of mutagens. Among all mutagens, NG exhibited as the most effective mutagen. The lower dose of NG $(0.005 \%)$ was recorded as the most effective and efficient among all mutagenic treatments. Among combined treatments, gamma rays with NG were found as more effective than other mutagenic combinations whereas gamma rays with EMS were found as the more efficient mutagenic combination. Among all mutagens, the maximum mutation rate based on lethality and pollen sterility observed in gamma rays treatments. 
physiological, and morphogenetic changes in cells and tissue (Gunckel and Sparrow, 1961; Das and Prusti, 2020). Among the chemical mutagens used for induction of both macroand micro-mutations in various crops, Ethyl methane sulfonate (EMS) and Nitrosoguanidine (NG) are the most effective, efficient, and frequently used mutagens (Minocha and Arnason, 1962; Swaminathan et al., 1968; Das \& Baisakh, 2020). Maleic hydrazide $(\mathrm{MH})$ which is an isomer of uracil also widely used in mutation breeding for the creation of genetic variability as it induces chromosome breaks and aberrations that are localized in heterochromatic regions near the centromere of the chromosomes (Darlington and McLeish1951). However, it is observed that only a few mutagenic treatments have been effective in inducing a high frequency of mutation while in others the frequency of induced mutation is low leading to wastage of resources. A highly effective mutagen may not necessarily show high efficiency and vice versa. The worth of mutagens in mutation breeding depends not only on its mutagenic effectiveness but also on its mutagenic efficiency. The choice of effective and efficient mutagens is very essential to recover a high frequency and spectrum of desirable mutations (Usharani and Kumar, 2015; Vairam, 2017; Das and Baisakh, 2020). Thus early knowledge of the relative biological effects of various mutagens and their selection is essential to recover the high frequency of desirable mutations (Das et al., 2006; Badere and Chaudhary, 2007; Das and Prusti; 2020).

Hence a study was undertaken to assess the effect of different doses of gamma rays, EMS, $\mathrm{NG}, \mathrm{MH}$ and their combinations on the frequency of chlorophyll mutation, lethality, and pollen sterility to evaluate the relative effectiveness and efficiency of different mutagenic treatments and the mutation rate for different mutagens.

\section{Materials and Methods}

Dry and well-filled seeds of a greengram variety, namely OBGG-52 administered mutagenic treatments with three doses each of Gamma rays $(20,40$ and $60 \mathrm{kR})$, Ethyl methane sulphonate $(0.2,0.4$ and $0.6 \%)$, Nitrosoguanidine $(0.005,0.010$ and $0.015 \%)$ and Maleic hydrazide (0.01, 0.02 and $0.03 \%$ ) singly and combine mutagens of $40 \mathrm{kR}$ gamma rays with $0.4 \%$ EMS or $0.010 \% \mathrm{NG}$ or $0.02 \% \mathrm{MH}$. The twelve single mutagenic treatments of gamma rays, EMS, NG, and MH were coded as G1, G2, G3, E1, E2, E3, $\mathrm{N} 1, \mathrm{~N} 2, \mathrm{~N} 3$, and $\mathrm{M} 1, \mathrm{M} 2$, and $\mathrm{M} 3$, respectively. Three combined treatments of $40 \mathrm{kR}$ gamma rays $+0.4 \%$ EMS, $40 \mathrm{kR}$ gamma rays $+0.01 \% \mathrm{NG}$ and $40 \mathrm{kR}$ gamma rays $+0.02 \% \mathrm{MH}$ were coded as GE2, GN2 and GM2, respectively. Dry seeds were irradiated with gamma rays treatment at Bhaba Atomic Research Centre (BARC), Trombay. For treatment with EMS, NG, and $\mathrm{MH}$, the seeds were pre-soaked in distilled water for six hours, blotted dry and then treated with a freshly prepared aqueous solution of the above chemical mutagens for 6 hours, with intermittent shaking. For combination treatments, seeds were first irradiated with $40 \mathrm{kR}$ gamma rays and then treated with $0.4 \%$ EMS or $0.01 \% \mathrm{NG}$ or $0.02 \% \mathrm{MH}$ solution in the same manner as described above. After treatment, the seeds were thoroughly washed with running water to bleach out the residual chemicals and then dried on blotting paper after treatment. To grow the $M_{1}$ generation, the treated seeds were sown in RBD in two replication with a spacing of $25 \times 10 \mathrm{~cm}^{2}$. Observations on survival were recorded in each plot at the time of maturity and were calculated as the percent of control from which the lethality \% calculated. Mean pollen sterility was determined based on acetocarmine stainability. The harvested selfed seeds of all 
survived plants were used to grow the $\mathrm{M}_{2}$ generation in RBD with three replications with a spacing of $25 \times 10 \mathrm{~cm}^{2}$. Different types of chlorophyll mutants were recorded daily from the 5 th to 12 th day after sowing. The treated and control populations were screened for different chlorophyll mutations (such as Albina, Xantha, Chlorine, Striata and Viridis) and calculated the frequency of chlorophyll mutation (Gaul, 1960). The mutagenic effectiveness and efficiency were calculated based on the formula proposed by Konzak et al., (1965).

M

Mutagenic effectiveness $=$ (Physical mutagen) Dose of mutagen in kR

$\begin{array}{lc}\begin{array}{l}\text { Mutagenic effectiveness }= \\ \text { (Chemical mutagens) }\end{array} & \mathrm{M} \\ & \mathrm{c} \times \mathrm{t} \\ \begin{array}{l}\text { Mutagenic effectiveness }= \\ \text { (Combination) }\end{array} \quad \text { Dose of physical mutagen in kR } \times \mathrm{C} \times \mathrm{t}\end{array}$
Mutagenic efficiency $=$

$\%$ Lethality $(\mathrm{L})$ or \% Pollen sterility(P)

$\mathrm{M}=$ Mutagenic Frequency of chlorophyll i.e. frequency expressed in percentage of total chlorophyll mutations in $\mathrm{M}_{2}$ generation..

$\mathrm{t}=$ Duration of treatment with chemical mutagen in hours.

$\mathrm{c}=$ Concentration of chemical mutagens in percentage

$\mathrm{L}=\%$ Lethality in $\mathrm{M}_{1}$ generation

$\mathrm{P}=\%$ Pollen sterility in $\mathrm{M}_{1}$ generation

Mutation rate (MR) which provides the knowledge of mutations induced by a particular mutagen irrespective of dose or concentration was calculated as follows.

$$
\begin{gathered}
\text { Mutation rate }=\text { - }- \text { Sum of values of efficiency of particular mutagen } \\
\text { Number of treatments of a particular mutagen }
\end{gathered}
$$

\section{Results and Discussion}

In the present study, biological damages like lethality and pollen sterility were recorded in $\mathrm{M}_{1}$ generation (Table-1). Both parameters were found to increase with increasing doses of mutagens (Fig-1). In gamma-rays treatments recorded maximum lethality $24.0 \%$ and pollen sterility $6.71 \%$ at $60 \mathrm{kR}$ whereas minimum lethality $12.5 \%$ and pollen sterility $1.06 \%$ at $20 \mathrm{kR}$. In the case of EMS treatments, the maximum lethality $(51.0 \%)$ was observed at $0.6 \%$ and the minimum $(21.5 \%)$ at $0.2 \%$. The pollen sterility increased with increasing doses of EMS i.e. $1.62 \%$ at a low dose to $5.89 \%$ at the higher dose $(0.6 \%)$. Similar trends were also found in other chemical mutagens $\mathrm{NG}$ and MH. In NG recorded maximum lethality $(29.7 \%)$ and pollen sterility $(9.03 \%)$ at $0.015 \%$ dose whereas minimum lethality $(15.0 \%) \&$ pollen sterility $(1.67 \%)$ at $0.005 \%$. In $\mathrm{MH}$ the lethality varies from $42.7 \%$ at $0.01 \%$ dose to $66.0 \%$ at $0.03 \%$ dose and pollen sterility from $2.68 \%$ to $10.23 \%$. In combined treatments of gamma-ray with NG recorded minimum lethality $(26.5 \%)$ whereas gamma-ray with EMS recorded minimum pollen sterility (3.18\%). Maximum lethality $(62.5 \%)$ and pollen sterility (8.6\%) observed in gamma rays with $\mathrm{MH}$ combinations. The increased lethality and pollen sterility with increasing doses of mutagens also reported by several investigators in greengram (Das et. al.,2006; Tah, 2006, Kouser et al., 2007, Das and Baisakh, 2020, Das and Prusti, 2020), in blackgram (Jain and Khandelwal,2008; Sagade and Apparao, 2011) and in clusterbean (Bhosle and Kothekar, 2010). They proved that most of the higher doses of mutagens showed increased pollen sterility 
and lethality. The probable reason for increased pollen sterility might be meiotic irregularities such as translocations.

Chlorophyll mutations provide one of the most dependable indices for the evaluation of genetic effects of mutagenic treatments and have been reported in greengram and other crops by several workers (Das et al., 2006; Singh, 2007; Thilagavathi and Mullainathan, 2009; Goyal and Khan, 2010; Vikram et al., 2014). Since chlorophyll deficient mutants could not survive long and observed in treated population for a variable-length period depending on the deficiency of chlorophyll. Therefore, these mutants are of no agronomic value but their frequency in different mutagenic treatments of $\mathrm{M}_{2}$ generation was considered to be a standard measure for estimation of effectiveness, efficiency, and rate of induced mutation by different mutagens which would ultimately provide information about the dose for inducing mutations in greengram. Chlorophyll mutation frequency is the frequency of chlorophyll mutations calculated on the $\mathrm{M}_{2}$ population basis (Table-1, Fig.-2). The frequency of chlorophyll mutation in different treatment in $\mathrm{M}_{2}$ generations varied from $0.27 \%$ (GM2) to $2.10 \%$ (E2). Considering the spectrum of different types of chlorophyll mutations, it was observed that the frequency of chlorina mutations was maximum followed by xantha mutations (Fig-2).

Table.1 Effectiveness and efficiency of different mutagenic treatments on greengram variety cv. OBGG-52

\begin{tabular}{|c|c|c|c|c|c|c|c|}
\hline \multirow[t]{2}{*}{ Code } & \multirow[t]{2}{*}{$\begin{array}{l}\text { Mutagenic } \\
\text { Treatments }\end{array}$} & \multirow{2}{*}{$\begin{array}{c}\% \text { of } \\
\text { lethality } \\
\text { (L) }\end{array}$} & \multirow{2}{*}{$\begin{array}{c}\% \text { of } \\
\text { Pollen } \\
\text { sterility } \\
\text { (S) }\end{array}$} & \multirow{2}{*}{$\begin{array}{l}\text { Frequency } \\
\text { of } \\
\text { chlorophyll } \\
\text { mutation } \\
\text { (M) }\end{array}$} & \multirow[t]{2}{*}{$\begin{array}{c}\text { Mutagenic } \\
\text { Effectiveness }\end{array}$} & \multicolumn{2}{|c|}{$\begin{array}{l}\text { Mutagenic } \\
\text { Efficiency }\end{array}$} \\
\hline & & & & & & $\begin{array}{c}\text { Based } \\
\text { on } \\
\text { lethality }\end{array}$ & $\begin{array}{c}\text { Based on } \\
\text { pollen } \\
\text { sterility }\end{array}$ \\
\hline G1 & Gamma-rays 20kR & 12.5 & 1.06 & 0.91 & 0.046 & 0.073 & 0.858 \\
\hline G2 & Gamma-rays $40 \mathrm{kR}$ & 15.5 & 3.14 & 1.42 & 0.036 & 0.092 & 0.452 \\
\hline G3 & Gamma-rays $60 \mathrm{kR}$ & 24.0 & 6.71 & 1.69 & 0.028 & 0.070 & 0.252 \\
\hline E1 & EMS $0.2 \%$ & 21.5 & 1.62 & 1.17 & 0.975 & 0.054 & 0.722 \\
\hline E2 & EMS $0.4 \%$ & 37.5 & 3.63 & 2.10 & 0.875 & 0.056 & 0.579 \\
\hline E3 & EMS $0.6 \%$ & 51.0 & 5.89 & 1.18 & 0.328 & 0.023 & 0.200 \\
\hline N1 & NG $0.005 \%$ & 15.0 & 1.67 & 1.44 & 48.000 & 0.096 & 0.862 \\
\hline N2 & NG $0.010 \%$ & 23.5 & 6.57 & 1.51 & 25.167 & 0.064 & 0.230 \\
\hline N3 & NG $0.015 \%$ & 29.7 & 9.03 & 0.78 & 8.667 & 0.026 & 0.086 \\
\hline M1 & MH $0.01 \%$ & 42.7 & 2.68 & 1.00 & 16.667 & 0.023 & 0.373 \\
\hline M2 & MH $0.02 \%$ & 55.5 & 7.45 & 0.80 & 6.667 & 0.014 & 0.107 \\
\hline M3 & MH $0.03 \%$ & 66.0 & 10.23 & 0.28 & 1.556 & 0.004 & 0.027 \\
\hline GE2 & $\begin{array}{c}\text { Gamma-rays } 40 \mathrm{kR}+ \\
\text { EMS }(0.4 \%)\end{array}$ & 35.0 & 3.18 & 1.65 & 0.017 & 0.047 & 0.519 \\
\hline GN2 & $\begin{array}{c}\text { Gamma-rays } 40 \mathrm{kR}+ \\
\mathrm{NG}(0.010 \%)\end{array}$ & 26.5 & 7.04 & 1.23 & 0.513 & 0.046 & 0.175 \\
\hline GM2 & $\begin{array}{c}\text { Gamma-rays } 40 \mathrm{kR}+ \\
\mathrm{MH}(0.02 \%)\end{array}$ & 62.5 & 8.60 & 0.27 & 0.056 & 0.004 & 0.031 \\
\hline
\end{tabular}


Table.2 Mutation rate of different mutagens in greengram

\begin{tabular}{|c|c|c|}
\hline Mutagens & $\begin{array}{c}\text { Mutation rate } \\
\text { based on lethality }\end{array}$ & $\begin{array}{c}\text { Mutation rate } \\
\text { based on pollen sterility }\end{array}$ \\
\hline Gamma-rays & 0.078 & 0.521 \\
\hline EMS & 0.045 & 0.500 \\
\hline NG & 0.062 & 0.393 \\
\hline MH & 0.014 & 0.169 \\
\hline Gamma rays +EMS & 0.047 & 0.519 \\
\hline Gamma rays +NG & 0.046 & 0.175 \\
\hline Gamma rays+ MH & 0.004 & 0.031 \\
\hline
\end{tabular}

Fig.1 Effect of different mutagenic treatments on lethality and pollen sterility in greengram

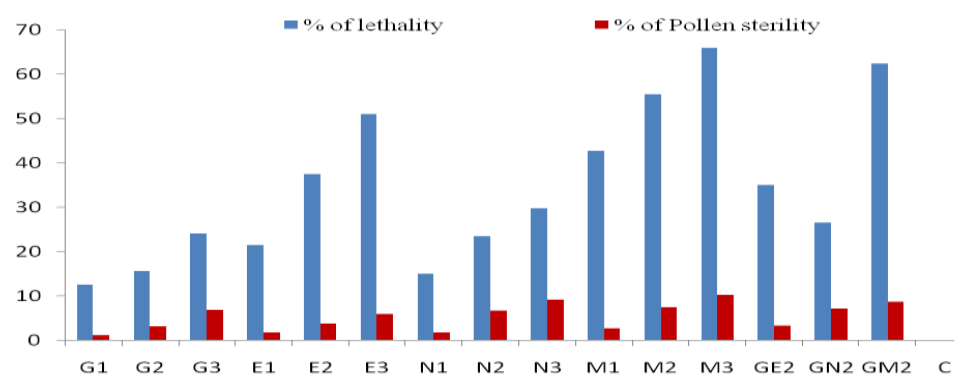

Fig.2 Frequency of chlorophyll mutations in different mutagenic treatments

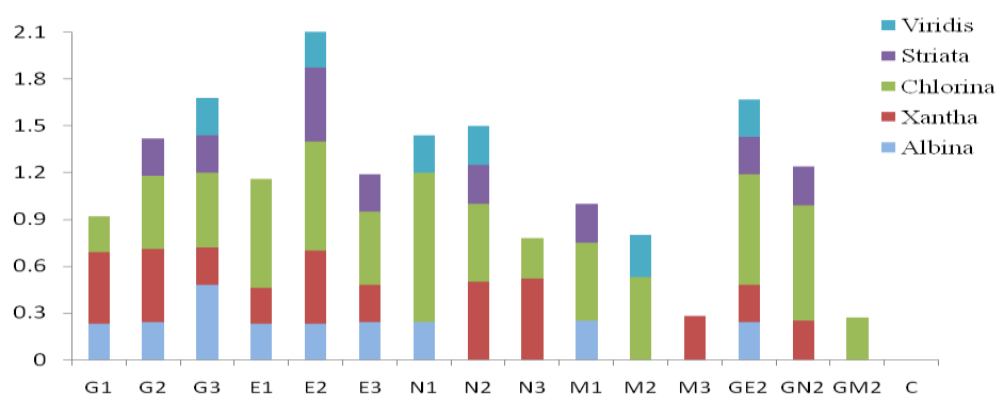

Fig.3 Mutagenic efficiency of different mutagenic treatments in greengram

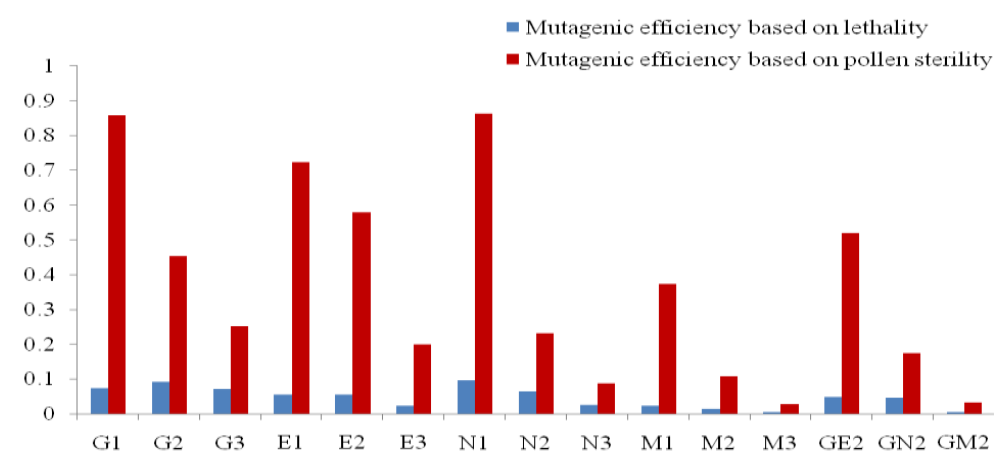


In this study, the relative frequency of chlorophyll mutants was increased with the dose of gamma rays whereas a reverse trend was found for MH treatments and in EMS and $\mathrm{NG}$, there was no dose-dependency relationship. In combined treatments, maximum chlorophyll mutation (1.65\%) recorded in GE2 followed by GN2. Similar results were also obtained by Das et al., (2006), Das \& Baisakh (2020). Bhosle and Kothekar (2010). The occurrence of chlorophyll deficient mutant was noticed due to changes in genes and a set of genes responsible for chlorophyll mutations (Monika and Seetharaman, 2017).

The mutagenic effectiveness of all the mutagens decreases with the increase of their doses/concentration. Among the different doses of gamma rays irradiated, the mutagenic effectiveness was maximum (0.046) at $20 \mathrm{kR}$ followed by $40 \mathrm{kR}$ (Table 1 ). In EMS, the mutagenic effectiveness was maximum $(0.975)$ at $0.2 \%$ followed by $0.4 \%$. In the case of NG, the mutagenic effectiveness was maximum (48.0) at $0.005 \%$ followed by $0.01 \%$ (25.165), and in $\mathrm{MH}$, the mutagenic effectiveness was maximum (16.667) at $0.01 \%$ followed by $0.02 \%$ (6.667) treatment. Hence it could be concluded that NG has higher mutagenic effectiveness compared to all other mutagens and lower doses are more effective among different doses of each mutagen. Similar results were previously reported by Sharma et.al. (2005), Das and Baisakh (2020), Das and Prusti (2020). On the contrary to the present study, Siddiq and Swaminathan (1968) found that EMS was the most efficient mutagen followed by gamma rays and NG. Among the combined treatments, the maximum effectiveness observed in gamma-rays (40kR) with $\mathrm{NG}(0.01 \%)$ combination followed by gamma-rays $(40 \mathrm{kR})+\mathrm{MH}(0.01 \%)$. The greater effectiveness of chemical mutagens over physical mutagen has also been reported by Satpute and Fultambkar (2012), Das and Baisakh (2020), and Das and Prusti (2020).

Konzak et al., (1965) showed that mutagenic efficiency provides the best available measure to evaluate different mutagenic treatments. It varies depending upon the criteria selected for its estimation. Nilan and Konzak (1961) and Konzak et al., (1965) opined that higher efficiency at the lower concentration of a mutagen is due to the fact that biological damage (lethality and sterility) increased within dose at a faster than the mutations. In the present investigation, mutagenic efficiency based on the lethality in $\mathrm{M}_{1}$ varied from 0.004 (M3) to $0.096(\mathrm{~N} 1)$ and observed that there is no dose-dependent relationship for gamma rays and EMS whereas in NG and $\mathrm{MH}$, as the dose increased the efficiency reduced. The value of efficiency based on pollen sterility decreased as there were increases in doses of mutagens (Table-1, Fig$3)$. It was ranged from $0.858(\mathrm{G} 1)$ to $0.252(\mathrm{G} 3)$ in gamma- rays treatment. In EMS treatments, the range was $0.722(\mathrm{E} 1)$ to 0.200 (E3) whereas in $\mathrm{NG}$, the range was $0.862(\mathrm{~N} 1)$ to $0.086(\mathrm{~N} 3)$ and in $\mathrm{MH}$ it was $0.373(\mathrm{M} 1)$ to $0.027(\mathrm{M} 3)$. The efficiency based on pollen sterility varied from $0.031(\mathrm{GM} 2)$ to $0.519(\mathrm{GE} 2)$ in the case of combined treatments. Based on Lethality and pollen sterility, $\mathrm{NG}(0.005 \%)$ was recorded as the most efficient mutagenic treatment among all treatments whereas the lowest efficiency was observed in $\mathrm{MH} 0.03 \%$ treatment. Higher efficiency at lower doses of mutagen as observed in the present study might be because of pollen sterility increased with an increase in doses at a rate faster than the frequency of mutation. Mutagenic efficiency increased with an increased dose similar results were also noticed by Awnindra (2007) and Velu et.al. (2008) in greengram.

The mutation rate for different mutagens provides an idea of the average rate of 
mutation induction per mutagen. The mutation rates are estimated from the value of mutagen efficiency based on lethality and pollen sterility (Table-2). Based on lethality and pollen sterility, a higher mutation rate was observed for gamma rays and a lower value of mutation rate for $\mathrm{MH}$. In the case of combination mutagenic treatments, Gammarays with EMS recorded a higher mutation rate than other combinations followed by Gamma-rays with NG. It could be noted that when the mutation rates based on efficiency were considered, the order of mutagens changes as the mutagens have varied values based on lethality and pollen sterility. Mutation rate based on lethality studies framed as Gamma rays>NG > Gamma rays $+E M S>$ Gamma rays $+N G>E M S>$ $M H>G a m m a$ rays $+M H$, whereas based as pollen sterility the mutation rate could be framed as Gamma rays > Gamma rays $+E M S$ $>E M S>N G>$ Gamma rays $+N G>M H>$ Gamma rays $+M H$.

A mutagen is useful only if it is effective as well as efficient. The effectiveness and efficiency of mutagen based on leaf chlorophyll mutation, lethality, and pollen sterility in greengram are useful in identifying the genetic effect of mutagen. In a mutation breeding program, a high mutation rate accompanied by minimal deleterious effects is desired. But generally, the mutagen that gives the higher mutation rate also induces a high degree of lethality, sterility, and other undesirable effects. In this study, lower doses of mutagens are more effective than their higher doses i.e. mutagenic effectiveness decreased with an increased dose in all the mutagens. The study also reveals the Gamma rays, EMS, NG, and their combinations have a higher potential to induce significant mutations in greengram and the lower dose of NG $(0.005 \%)$ recorded as the most effective and efficient among all mutagenic treatments. It was observed that when the mutation rate based on efficiency was considered, the order of mutagen changes according to the value of lethality and pollen sterility. Among all mutagens, the maximum mutation rate based on lethality and pollen sterility observed in gamma rays treatments.

\section{References}

Awnindra, K.S. 2007. Mutagenic effectiveness and efficiency of gammarays and ethyl methane sulphonate in mungbean. Madras Agric. J. 94(1-6): 713.

Badere, R.S. and Chaudhary, A. D. 2007. Effectiveness and efficiency of Gamma rays, Sodium azide and Ethyl methane sulphonate in Linseed. Bioinfolet., 4(3): 181-187.

Baisakh, B., Das T. R. and Nayak, B. K. 2011. Efficacy of physical and chemical mutagenic treatments in developing desire micro-mutants of urdbean. Journal of food legumes. 24 (2): 106109.

Bhosale, S.S. and Kothekar, V.S. 2010. Mutagenic efficiency and effectiveness in clusterbean (Cyamopsis tetragonoloba (L.) Taub.). J. Phytol. 2(6): 21-27.

Darlington, C.D and McLeish, J. 1951. Action of Maleic hydrazide on the cell. Nature (London) 167:407-408.

Das, T. R. and Baisakh, B. 2013 Efficacy of physical and chemical mutagenic treatments for developing superior mutants in greengram (Vigna radiata). Indian Journal of Agricultural Sciences. 83 (6): 595-598.

Das, T. R. and Baisakh, B. 2020 Effectiveness and efficiency of physical and chemical mutagens in greengram [Vigna radiata (L.) Wilczek]. e-planet. 18 (1): 6-12.

Das, T. R. And Prusti, A. M. 2020. Mutagenic Effectiveness and Efficiency of Gamma Rays, EMS and NG in Greengram 
(Vigna radiata L. Wilczek). Int. J. Curr. Microbiol. App. Sci. 9(4): 2336-2344.

Das, T. R. and Misra, R.C. 2005. Genetic analysis of mutagen induced variability in yield triats in greengrams (Vigna radiata). Environment \& Ecology. 23(2): 381-384.

Das, T. R., Misra, R.C. and Sahu, P.K. 2006. Efficiency of mutagenic treatments in expression of macro and micro mutations in $\mathrm{M}_{2}$ generation in greengram and its early predictability on basis of $\mathrm{M}_{1}$ parameters. Environment \& Ecology. 24(2):283-288.

Gaul, H. 1960. Critical analysis of the methods for determining the mutation frequency after seed treated with mutagens. Genet. Agr.12: 297-318.

Goyal, S. and Khan, S. 2010. Induced mutagenesis in Urdbean (Vigna mungo L. Hepper): a Review. Int. J. Bot. 6(3):194-206.

Gunckel, J.E. and Sparrow, A.H. 1961. Ionizing radiation: Biochemical, Physiological and Morphological aspects of their effects on plants. In: Encycl. Plant Physiol. (ed.) W. Ruhland. XVI.Springer-verlag, Berlin. pp. 555-611.

Jain, S.K. and Khandelwal, V. 2008. Mutagenic efficiency and effectiveness of EMS and DMS in blackgram (Vigna mungo (L.) Hepper). J. Arid Legumes, 5(2): 110-113.

Keatinge, J., Easdown, W., Yang, R., Chadha, M. and Shanmugasundaram, S. 2011. Overcoming chronical nutrition in a future warming world: the key importance of mungbean and vegetable soybean. Euphytica., 180: 129-141.

Konzak, C.F., Nilan,R.A. Wagner, J. and Foster, R.J. 1965. Efficient chemical mutagenesis. The use of induced mutations in plant breeding (FAO / IAEA Meeting, Rome). Radiat. Bot., (Suppl.) 75: 49-70.
Kouser, M., Suresh Babu, G. and Lavanya, G.R. 2007. Effects of mutagen on $\mathrm{M}_{1}$ population in urdbean. J. Food Legumes, 20(1): 109-110.

Minocha, J.L. and Arnason, T.J. 1962. Mutagenic effectiveness of ethyl methane sulfonate in barley. Nature, 196: 499-499.

Monika, S. and Seethraman, N. 2017. Induced chlorophyll and viable mutation in Lablab purpureus (L.) sweet Var. typicus through gamma rays and Ethyl Methane Sulphonate. Int J Pharm Bio Sci. 8(2): $240-249$.

Nilan, R. A, and Konzak, C. F. 1961. Increasing the efficiency of mutation induction. In: Mutation and Plant Breeding, NAS-NRC: 437-460.

Sagade, A.B. and Apparao, B.J. 2011. $\mathrm{M}_{1}$ generation studies in urdbean (Vigna mungo (L.) Hepper). Asian J. Exp. Biol. Sci., 2(2): 372-375.

Satpute, R.A. and Fultambkar, R.V. 2012. Effectiveness and efficiency of the mutagens gamma rays and EMS in soybean (Glycine max (L.) Merrill)., Curr. Bot., 3(2): 18-20.

Sharma, S. K, Sood, R. and Pandey, D. P. 2005. Studies on mutagen sensitivity, effectiveness and efficiency in urdbean (Vigna mungo (L.) Hepper). Indian J. Genet. 65: 20-22.

Siddiq, E. A, and Swaminathan, M. S. 1968. Enhanced mutation induction and recovery caused by nitroso- guanidine in Oryza sativa L. Indian J. Genet. 28 (3): 297-300.

Singh, A.K. 2007. Mutagenic effectiveness and efficiency of gamma rays and ethyl methane sulphonate in mungbean. Madras Agric. J. 94 (1-6): 7-13

Swaminathan M.S., Siddiq., E.A. Savin V.N. and Vargughese. G. 1968. Studies in the treatment of mutation frequencies and identification of mutation in plant Breeding and Phylogenetic significance 
of some cereals. Mutation in Plant Breeding, 11, IAEA, Vienna. 233-248.

Tah, P. 2006. Induced macromutations in mungbean [Vigna radiata (L.) Wilczek]. International Journal of Botany. 2(3):219-228.

Thilagavathi, C and Mullainathan, L. 2009. Isolation of macro mutants and mutagenic effectiveness, efficiency in blackgram [Vigna mungo (L.) Hepper]. Global J. Mol. Sci. 4:76-79

Usharani K.S. and Ananda Kumar C. R. 2015. Mutagenic efficiency and effectiveness of gamma rays and EMS and their combination in inducing chlorophyll mutations in $\mathrm{M}_{2}$ generation of Urdbean (Vigna mungo (L.) Hepper). Electronic Journal of Plant Breeding. 6(1): 210217.
Vairam, N. 2017. Effectiveness and Efficiency of Physical and Chemical Mutagens in $\mathrm{M}_{2}$ Generation of Greengram [Vigna radiata. (L.) Wilczek]. Trends in Biosciences. 10(22): 4329-4333

Velu, S., Mullainathan, L., Arulbalachandran, D., Poongkuzhalir and Dhanavel, D. 2008. Spectrum of morphological mutation and effectiveness and efficiency of physical and chemical mutagens in greengram. Int. J. Pl. Sci. 3(1): 1-4.

Vikram, N., Ibrahim, S. M. and Vanniarajan, C. 2014. Frequency and spectrum of chlorophyll mutations in greengram [Vigna radiata (L.) Wilczek]. Asian Journal of Bio Science. 9 (2): 204-207.

\section{How to cite this article:}

Tapas Ranjan Das, Bhabendra Baisakh and Arjun Mohan Prusti. 2021. Studies on Mutagenic Effectiveness and Efficiency of Gamma Rays, Ethyl Methane Sulphonate, Nitrosoguanidine, Maleic Hydrazide and their Combination in Greengram (Vigna radiata L. Wilczek). Int.J.Curr.Microbiol.App.Sci. 10(01): 3354-3362. doi: https://doi.org/10.20546/ijcmas.2021.1001.394 